\title{
Accounting for indebtedness: geopolitics, technocracy and advanced financial capital
}

\author{
Dr David Carter, Associate Dean of Research, University of Canberra.
}

Miss Rebecca Warren, PhD Candidate, Royal Holloway; Senior Lecturer in Accounting, Oxford Brookes. (corresponding author: Rebecca.warren.2013@live.rhul.ac.uk)

Word Count: 12,335

\begin{abstract}
This paper explores the role of accounting within the context of Lazzarato's theorisation of indebtedness. Accounting is often depicted as neutral, objective and technocratic, and despite Lazzarato referencing accounting within his exploration of indebtedness, we believe the role of accounting is underexplored in his analyses. Our intervention suggests that accounting is the primary language of financialisation, securitisation, financial capital and indebtedness. This paper also extends Lazzarato's thesis by arguing that, with new accounting technologies, indebtedness is being spread to emerging economies. This extension is mobilized through the work of the International Accounting Standards Board, as a private accounting standard setter, in partnership with the World Bank and the International Monetary Fund as accounting is language of advanced financial accounting and indebtedness.
\end{abstract}

\section{Introduction}

Lazzarato $(2012,2013)$ advances a thesis suggesting that neo-liberal social relations are organised around debt and subjection. Debt, in his argument, provides the means for the basis of social life, as credit pervades economic decision-making, life itself (insurance and welfare) and government. While a growing scholarship in critical policy studies and human geography focuses on the impact of debt on the politics of the value of life, we argue that accounting is under-represented in developing this understanding (Morgan 1988, Lazzarato 2012, 2013). The lessons of the financial crisis, the Eurozone debt crises and continued financial instabilities emphasise the centrality of advanced financialisation, the impact of continued liberalisation of financial/debt markets and the re-institutionalisation of the status quo postcrisis through debt-funded bailouts. There is an historical dimension to accounting being employed as a language of business and government to rationalise the value of life (see, Hoffman 1984, Wolcher 2007). We argue that accounting is a central technology within the neo-liberal agenda of austerity, indebtedness, privatisation and liberalisation, as developments in accounting over the last twenty years contribute to the language of advanced financial capital (financialisation, securitisation and fair value ${ }^{1}$ ) with impacts on the state, citizens and international financial institutions [IFIs] (including, The World Bank, the

\footnotetext{
${ }^{1}$ The International Accounting Standards Board defines fair value as “... an amount at which an asset could be exchanged between knowledgeable and willing parties in an arms length transaction". This measurement technique is commonly applied to financial transactions, including financial instruments and derivative financial products (this is part of financialisation and central to advanced financial capital. Specifically, IFRS 13 Fair Value Measurement applies the following valuation hierarchy: Level 1: fair values are derived from quoted market prices for identical assets or liabilities from an active market for which an entity has immediate access; Level 2: where there are market prices available for similar (as opposed to identical) assets or liabilities; and Level 3: if values for levels 1 or 2 are not available, fair value is estimated using valuation techniques. Please see IFRS 13 for further details. Also, there is a more detailed discussion of fair value under the sub-heading "Accounting as the technology for the valorisation of futures and social life".
} 
International Monetary Fund, Development Banks and the International Accounting Standards Board [IASB]). Lazzarato $(2012,29)$ argues that the "power bloc of the debt economy has seized on the latest financial crisis as the perfect occasion to extend and deepen the logic of neoliberal politics'. The purpose of this paper is to reflect on the implications of a hegemonic shift between national capitalisms and a genuflection towards financial capital, and to illustrate the central role of accounting in this process. This is particularly resonant due to the impact of the global financial crisis [GFC], and the increase in indebtedness with respect to both individual indebtedness and the indebtedness of sovereign nations (Lazzarato 2012, 2013, Graeber 2011, Mellor 2010).

There has been a dramatic shift in the forms, range and extent of financialisation in economies and in society. Financialisation is both a measure of the importance of the growth of financial capital in economies, but is also indicative of a subjective and emotional relationship for individuals facing daily economic decisions. The ease of getting access to credit is indicative of both impacts. In Mellor's (2010) study of the Financial Crisis, the significance of the financial growth of derivative markets is distinctive. For example, the credit default swap market grew from $\$ 108$ billion in 1995 to $\$ 45.5$ trillion in 2007. This is central to the thesis of this paper: debt is not new, but access to debt (arguably from the 1970s onwards) has increasingly become easier and the nature of debt products and opportunities equally is subject to change. This, for us, is important, as it justifies the need to account for indebtedness as the literature in accounting and politics does not fully reconcile the implications of these recent changes. There are two co-relative trends that illustrate the scope of indebtedness: individual households are more in debt than at any point in time: UK household debt at the height of the financial crisis peaked at 150 per cent (Mellor 2010), but furthermore, governments themselves, are increasing turning to financial markets to 'borrow' to pay fundamental social services (Lazzarato 2012). Indebtedness is both direct (to individuals) and indirect (through sovereign debt). We use this foundation to make three inter-related arguments: 1) that accounting is an active agent in the 'politics' of the genuflection to financial capital and debt as central to Lazzarato; 2) that the IASB operates as a geopolitical agent with significant 'hidden' power, orchestrating technologies necessary to support hegemony of financial capital and indebtedness; and 3) that accounting provides the technologies for the valorisation of futures and social life itself. To do this, we introduce the foundations of indebtedness, which, in our opinion, centre on time, measurement and the value of social life.

\section{Lazzarato and the Making of the Indebted Man}

Lazzarato $(2012,2013)$ suggests that a hegemonic shift towards financial capital and away from traditional capitals, such as industrial or knowledge capital, is taking place (Harvey 2010). This suggests that indebtedness is emerging as a master signifier of financial valorisation, as debt is a measure of the value of social life. The first element in unpacking this claim is that financial capital travels across borders more easily than other forms of capital - the relevant production processes (both material and immaterial) of industrial and knowledge capital remains 'grounded in the body' (Spence and Carter 2011, 305) and thus, this renders these capitals subject to national capitalist controls, such as immigration restrictions, nationalisms and macro-economic controls such as inflation (Mellor 2010). In this sense, financial capital is freer of such constraints; note for example, international capital mobility was a founding goal of international accounting harmonisation (Botzem 2012). Lazzarato (2012) demonstrates that there has been a move to financial capital that prioritises credit and debt, as an evolution from Fordist regulation. The central relationship, in this post- 
Marxist presentation of social relations, is the creditor-debtor relationship. In this we are also recognising a hegemonic shift from stage one financial capital towards advanced financial capital (as indicated by the creditor-debtor relationship). Traditional financial capital takes the form of direct investment as observed through advanced capital economies investing, for example, in manufacturing facilities (see Klein's (2007) exposition of export-processing zones) and in share markets, but the increasing financialisation through derivative financial products and the extension to the debtor-creditor relationship is indicative of why debt is becoming the master signifier of financial valorisation: indebtedness is a central signifier of financial capital and thus, indebtedness is central to valorisation. Within this connection accounting plays a crucial role (in valorising indebtedness) as indebtedness is about 'purchasing' futures. Our intent is to illustrate how accounting is developing new technologies to measure and valorise these futures for profit.

Lazzarato (2012) argues that society (including both individual subjects and governments) operates now as 'indebted man', as was evident during and after the financial crisis. The traditional construction of capital suggested a crucial co-production role for the state, in the sense of superstructural support for the economic base. However increasingly, financial capital renders the state more precarious as increasingly state welfare is funded through debt, and the experiences of Greece and other states illustrate that financial capital will attack the state. Debt, in the context of state debt, suggests a range of different options: raising money through 'patriotic' bonds to be bought by any citizen, borrowing from other countries, from banks, from the IMF, or raising money through financial markets and sophisticated financial instruments) that have different implications. Irrespective of the multi-various forms of state indebtedness, they continue to re-create the debtor-creditor relationship (that is, the same subjectivities), as these debt products are linked to global capital movement and financial capital. While traditional capital is founded in languages of exchange, debt is the master signifier of 'neo-liberalism'. As Deleuze $(1995,181)$ argues: 'A man is no longer a man confined, but a man in debt'. This constitutes a shift to financial capital in a control society, as '[d]ebt constitutes the most deterritorialised and the most general power relation through which the neoliberal power bloc institutes its class struggle' (Lazzarato 2012, 90).

Lazzarato, drawing on Deleuze and Guttari, reconceptualises Foucault's concepts of biopolitical power and governmentality as being more than "technologies of control" by interrogating why these technologies exist. Lazzarato $(2012,8)$ extends the idea of 'power' to futures:

Neoliberal governmentality... is no longer conducted exclusively by the state, but by an ensemble of non-state institutions (such as 'independent' central banks, markets, pension funds, etc.) which the state administers only in terms of an admittedly important articulation. This functioning is exemplified in the crisis by the Troika of the IMF, the EU and the European Central Bank.

This reading radicalises governmentality and the biopolitical, as traditional Foucault founded the concept of the biopolitical (production of a social body) subject to State power. By extending the biopolitical beyond the States and across time, this allows financial organisations and financial capital, through debt, to 'control' populations of 'debt-holders'. This also allows traditional Foucauldian constructs such as non-conformance to extend to the debt relationships, and this is illustrative of the extension of governmentality, the 'control' powers exercised by financial capital through indebtedness. This extends governmentality outside of the traditional 'capillaries' of power to non-state financial capital. The argument is that debt becomes a logic of 'self-regulation'. For financial capital, the debt relationship 
reflects a valuation of social life as it creates the 'perfect storm' for continued exploitation and appropriation as the debtor is "more or less in debt, more or less poor, but in any case always precarious" (Lazzarato 2012, 95).

In terms of measurement and scope, Lazzarato argues that there are two levels of indebtedness, direct and indirect. Direct indebtedness concerns personal indebtedness and the ease of credit for the everyday subject. Indirect indebtedness focuses on state indebtedness, and therefore means that the subject is born into debt for being a member of a national capitalism in which the state is in debt. Within this state indebtedness, the state is under attack from financial capital, as the state represents another way of making money (Lazzarato 2012, 115):

The debt problem is still very much with us. It has only shifted from private debt to sovereign State debt. The enormous sums that states have handed over to banks, insurance companies, and institutional investors must now be "reimbursed" by the taxpayers (and not by the stakeholders and purchasers of stock). The highest costs will be borne by wage-earners, beneficiaries of public programs, and the poorest of the population.

The concept of time is central here: the role of debt in indebtedness is to exercise control in the moment. In short, the privatised governance of debt focuses on requiring debtors to respond to creditors in 'real time'. In a neo-liberal economy of debt, debt operates not only as an economic mechanism, but as a form of governance:

... aimed at reducing the uncertainty of the behaviour of the governed. By training the governed to 'promise' (to honour their debt), capitalism exercises 'control over the future' since debt obligations allow one to foresee, calculate, measure, and establish equivalences between current and future behaviour. The effects of the power of debt on subjectivity (guilt and responsibility) allow capitalism to bridge the gap between present and future' (Lazzarato 2012, 45-46).

Debt acts as a "capture", "predation", and an "extraction" machine on the whole of society (Lazzarato 2012, 29). For Lazzarato (2012), neo-liberalism is concerned with reprivatisation of money and power, and money is crucial to the analysis of market and competition. As Deleuze and Guattari $(1975,272)$ argue, 'it is banking that props up the whole system and the investment of desire', adding: 'it is money and the market that truly police capitalism' (284). Indeed, for Lazzarato $(2012,7)$ '[e]veryone is a "debtor", accountable to and guilty before capital'.

This central question within this 'exploitative inclusion' is the allure of debt. The reason that everyone is a 'debtor' is due to the 'power' of measurement within indebtedness which incorporates the bio-political and serves the neoliberal agenda of evaluation and measurement. Lazzarato $(2012,43)$ argues that:

Man is a 'calculating animal'. But the origin of calculation, measure, evaluation and accounting (all of which are also functions of money) must not be sought in economic exchange or in labour, but in debt. Indeed, equivalence and measure are not the products of exchange, but of the calculation of guarantees of debt repayment.

This is a logic reinforced by Lazzarato $(2012,20)$, as we carry the mechanism to subjectivate ourselves (by indebting ourselves):

We carry within us the creditor-debtor relation in our pockets and wallets, encoded in the magnetic strip on our credit cards. Indeed, this little strip of plastic hides two seemingly 
harmless operations: the automatic institution of the credit relation, which thereby establishes permanent debt. The credit card is the simplest way to transform its owner into a permanent debtor, and "indebted man" for life.

The subjectivation that comes from debt (both direct and indirect) suggests that there are attempts to render us all 'subject' to debt. Indeed, the pervasiveness of debt suggests that debt is 'central to understanding ... neo-liberalism' (Lazzarato 2012, 25).

The concept of control is significant within the debt relationship and has been the subject of significant debate in recent anthropological literature. Peebles (2010) argues that credit and debt are powerful, regulating society, space, time and the body through morality (Gregory 2012). Guérin (2014) in a micro-credit context, examines the ability of debt to reconfigure dependence and the misery and despair that flows from over-indebtedness, while in a similar vein, Sneath (2012) argues through an examination of Mongolian pastoralists that debt creates a form of dependency and the privatisation and separation of assets once communal. Thus, debt is a coloniser. Graeber's (2011) substantive sweep through a political economy of debt illustrates many of these arguments, reinforcing the link between morality and debt and tracing this to violence and slavery. In particular, the incorporation of the 'anxiety' that flows from the servitude of slavery into the servitude of indebtedness is illustrative. Graeber (2011, 4) argues that, 'debt has come to be the central issue of international politics'. Graeber's analysis is based on a vast reading of human society and reads through different debt epochs, while Lazzarato is embedded in a reading of theory (such as Nietzsche and Deleuze and Guattari).

The impact of debt is crucial today as debt penetrates many aspects of our lives and our decisions, conscious and subconscious. Debt operates to constrain futures. Progressively the measure of indebtedness is not monetary per se but it incorporates the purchase of time in the sense of the purchase of futures: '[d] ebt bridges the present and future' (Lazzarato 2013, 70). Traditional time measures were productive in origin through the Fordist focus of industrial capital; time is expropriated through immaterial valorisation, but an expression of debt, is not simply a measure of indebtedness, but a measure of future time. A 25-year mortgage, for example, is not simply a liability, but is an expression of the creditor-debtor relationship, and is an expression of the control exercisable over the debtor by the debt relationship to the creditor. The debtor is constrained and restricted by the debt instrument: this subjectivates the subject in both a physical sense, but also in a moral sense as well. The hidden power of the bio-politics of debt (and the value of life) is that debt subjectivation penetrates your life, your social life and your decisions, as your indebtedness constrains your options, limits your futures and restrains decisions and choices. Moreover, the semiotic of debt has the ability to impact deeply, because it constrains futures, so it has the power to capture many elements of subjectivation.

Coleman (2016) argues that this is relevant to the current financial instability post-GFC, as Coleman (2016) austerity extends the means of neoliberal capital. For Coleman $(2016,97)$, the pessimism extends beyond the implication that futures are constrained, but actually, it is more complete: indebted man or woman has no future. In drawing on Mol and Law (2004), this is what debt does to you - being in debt is a state of existence, but living with debt is living constrained and futureless. This is the concept of financialisation as a lived process (García-Lamarca and Kaika 2016), which supports the hegemonic genuflection to financial capital as evidenced by indebtedness.

We believe that accounting is firmly at the forefront of this genuflection, but we argue that 
the mistaken belief in the 'technocratic' nature of accounting (both from a regulatory and a practitioner perspective) operates to mask accounting as a 'hidden power' within the discourse of indebtedness. Lazzarato (2012, 100-101) does recognise a role for accounting here as the language of capital and as the language of subjectivation from financial capital, arguing that:

[Accounting] dictates to and imposes upon private firms a new 'measure' of value, implemented through new international accounting standards ... developed in the exclusive interest of investors and shareholders ... The new accounting is supposed to allow for comparisons between companies' financial performance at any point in time and for any business sector.

The mistake here is to think that money is an instrument of financial capital: money is merely 'an accounting tool'. In other words, it is not a "thing" at all (Graeber 2011, 46). Debt and indebtedness are the control mechanisms of financial capital and accounting has been constructed to play a role as a crucial language (Catlett 1960). Within Lazzarato's writings he makes references to, and implicates the role of, accounting in the violence of advanced financial capital hegemony, but the role of accounting is not really explained. What we seek to do is to focus specifically on the role of accounting and identify its centrality in a politics of indebtedness. To do this we will examine the existing literature that develops and applies Lazzarato's approach and continue to identify where accounting is excluded or overlooked from the analysis. We argue that the extension of accounting for indebtedness is significant and requires further research.

\section{Research that interrogates Lazzarato's indebted man}

Time, measurement and the value of social life (central concepts within Lazzarato) all resonate with the accounting discourse. We hold that accounting is key to an understanding of debt:

Credit Theorists insisted that money is not a commodity but an accounting tool. In other words, it is not a "thing" at all. You can no more touch a dollar or a deutschmark than you can touch an hour or a cubic centimetre. Units of currency are merely abstract units of measurement, and as the credit theorists correctly noted, historically, such abstract systems of accounting emerged long before the use of any particular token of exchange (Graeber 2011, 46).

This linkage of accounting to debt is reinforced by Adkins (2017) who focuses on the relationship of a debtor to their debt and the impact on 'time'. The invocation of 'debt' has the effect of rewriting time (Adkins 2017, 3), as a form a deferral of the present to the future:

Debt therefore allows deferral in (and of) the present but at the expense of a contracted out future, that is, at the expense of a future which is already plotted and mapped, a future which is known before it has arrived. Debt, or the promise to pay, therefore operates via a double move in regard to time: it defers the present but does so by counting on (and counting) the future.

Debt shifts from a logic of payment to a logic of repayment, and from the probable to the impossible. Indebtedness, in this sense, is not about what you have to pay, but rather it is about what you could pay. Under this logic, the potential amount of debt grows. This promise to pay leads to defining debt through time. Lazzarato recognises that this is about constraining futures, but Adkins $(2017,4)$ argues that this is about binding futures in two 
ways: individuals are bound to the terms of the promise and to the future that the promise entails: 'In the society of mass debt, modern day moneylenders therefore do not only appropriate money, they also appropriate time'. This relates to Guyer's (2012) analysis of the calendrics of debt, which is explained as:

\begin{abstract}
... the calendrics of debt afford the society of debt not a present emptied out or dispossessed of time, or a society in which time is appropriated by the operations and architectures of debt, but one which opens out a distinct universe organised and defined by the rhythms and sensations of steadiness ... In short, the extensive time universe of the calendar enables the conversion of time into money, a conversion which is pivotal to the process of accumulation via debt analysis of the calendrics of debt (Adkins 2017, 453).
\end{abstract}

This is a common concept within accounting, as the accrual accounting process reconstructs 'money' into recognisable pockets of 'time'. As we illustrate later in the paper on page 13, techniques of accounting such as fair value provide a mechanism for capturing future value in today's accounting, which deconstructs and reorganises time. Furthermore, the short-termist nature of accounting and representing valorisation e.g. continuous reporting, annual reporting, forecasting, quarterly reporting and the accruals of accounting reifies this calendrics of debt as it deconstructs and reconstructs conceptions of time.

Furthermore, Lazzarato's depiction of debt as about purchasing future life has a further implication, suggesting that the real impact of financialisation and financial capital is the predation of social life itself [this extends Hardt and Negri $(2005,2009)$ ]. Terranova (2015, 19) suggests that financialisation and capitalism constitutes a new 'tragedy of the commons', due to the associated destruction of social life. The argument centres on the protection of the markets and the influence of austerity-based politics is the destruction of society. Terranova $(2015,17)$ argues

If the market does not work, neoliberals argue, it is society's fault and hence it is society which must change, even at the cost of breaking it apart. The state no longer safeguards the social bond but either destroys it or radically weakens it in order to achieve 'complete conformity to the market'. It is in order to make the market free, then, that society must be enslaved.

In this, indebtedness is the appropriation of the present and of futures, but also of social life itself. Di Federici $(2014,234-235)$ similarly identifies that '.. what matters ... is ... that a debt economy was consolidated that has disarticulated the social fabric'. Allon (2010) extends the impact of financial capital and indebtedness one step further in arguing that the profit maximisation characteristic of debt-owners is that this financial investment mentality affects everyday life: "everyday life is increasingly framed as a space of investment yielding both financial and personal returns' (367). Vadrot (2012) discusses the multiple crises that we face in modern society, which has the effect of increasing uncertainty and insecurity, the impact of this is that some illusion of the stability of financial markets is masking an opportunity to question the power structure of financial capital and the systems we currently have. Vadrot $(2012,2017)$, is correct in asserting that this provides us with an opportunity to identify the hidden, 'technocratic' power structure of accounting for indebtedness as the hegemonic actor supporting the shift to financial capital.

Accounting is, we argue, a central aspect of financialisation, as the violence of indebtedness constrains and captures futures. New technologies of accounting, such as fair value and derivative-based accounting, capture and restate time, as these debt mechanisms have the accounting effect of bringing the future into the present (Adkins 2017, Guyer 2012). Furthermore, these financialisation measurement techniques appropriate the social lives of 
the indebted. These new accounting techniques for financial capital are predatory in two ways: first they valorise the future, operating to constrain futures and control individuals; and they valorise future life (through indebtedness being a form of enclosure of social life). For example, fair value accounting is used by organisations to capture value that will be earned tomorrow; the sale of mortgage-backed securities and credit default obligations, as characterised by the global financial crisis, allowed financial capital to bring future values forward to the present, whilst simultaneously controlling and constraining the social life of the debt holder. In a moral sense, financialisation and accounting are mechanisms for inscribing the memory of 'guilt' associated with the 'error' of debt. Debt renders us 'answerable for' our 'own futures' (Nietzsche 2006, 36). The effect of this accounting has the impact of rendering components of the future and social life as valuable commodities on the balance sheet of organisations participating in financial capitalism.

\title{
Accounting research and control
}

We believe that accounting functions as a 'hidden mechanism' within the debt relationship. Accounting operates to legitimise, mask and hide the appropriation of social life. However, in political economies of debt, accounting tends to be disregarded as technical, technocratic or 'objective', a characterisation that we disagree with. We argue that this belies a deep power structure, as accounting, in general, and accounting regulation, in the forming of standards, exercises significant geo-political power. This perceived 'neutrality' and technocracy obfuscates the politics of accounting as an instrument for exploitation and expropriation (Hines 1988, Puxty 1993, Gallhofer and Haslam 2003). Critical accounting literature challenges the hegemony of accounting, highlighting the social problems caused by accounting technologies (Shaoul 1997; Botzem 2012; Gallhofer and Haslam 2007, 2003). Accounting research illustrates the subjectivity, control and power of accounting technologies (Morgan 1988). Accounting is both shaped by society and shapes society (Gaffikin 2008, 239):

\begin{abstract}
Accounting is shaped by the demands placed on it, but it also shapes the environments with which it interacts. Consequently, accountants need to be aware of social, political, legal and linguistic considerations, and not just serve the economic interests of a few members of society.
\end{abstract}

The role of accounting as the language of capital exploitation is well-established (Harney 2005, 2006, Carter 2018). As Puxty $(1993,4)$ argues, '[a]ccounting is an instrument ... that facilitates the exploitation of, and extraction of surplus value from its employees by the capitalist interests'. Accounting operates to support the 'status quo' of inequality and inequity inherent within capitalism (Gallhofer and Haslam 2003). As Catlett $(1960,44)$ explains:

Accounting has been created and developed to accomplish various desired objectives and, therefore, it is not based on fundamental laws or absolute precepts.

The myth of objectivity obfuscates pluralistic approaches to accounting by covering over antagonisms and by reifying the rational calculative elements of accounting practice (Brown and Dillard 2013). Critical accounting research challenges the technocratic view that accountants are legitimated experts ${ }^{2}$ (Chua 1986, Hines 1991). Hines (1988, 257), argues:

\footnotetext{
2 There has been work in the social sciences that has examined the role of experts and expertise in the construction of social exclusion and inequality (Mitchell 2002, Vadrot 2017). Research has also considered the impact that numerical objectification of social phenomena can have in depoliticising political issues (Erkkilä and Piironen 2014).
} 
It seems to me, that your power is a hidden power, because people only think of you as communicating reality, but in communicating reality, you construct reality." "That's right. A hidden power. And all the more potent for it. This may sound silly to you, but most of us are only just beginning to realise ourselves that we have this power. We always thought of ourselves as being technical people. But it has been becoming clear lately, that there is much more to our work. Much more....

The nature of political research on accounting illustrates that accounting was developed as a tool for the maintenance and continuation of capitalist power relationships (Cooper and Sherer 1984, Arrington and Puxty 1991) and is a constitutive social process in 'itself' (Mouck 1992, Covaleski, Dirsmith and Samuel 2003, Major and Hopper 2005), subject to cultural variations between accountants and how they use accounting technologies and techniques (Gill 2009, Sherer and Arrington 1991). Accounting discourses create and sanction conceptions of 'truth' (Hines 1988). In demonstrating the powerful discourse of accounting, critical accountants expose how accounting dehumanises human beings by reducing social relations to measurable, countable entities, by excluding them from measurement, or by ignoring broader social and environmental issues (Puxty 1993, Gray 2001).

Accounting is not a neutral technology, but it has a limited and limiting frame of reference that colonises social situations. Critical accounting research, particularly with respect to management accounting, examines the impact of the World Bank and IMF structural adjustment programmes in emerging economies (Efferin and Hopper 2007, Wickramasinghe and Hopper 2005). Uddin and Hopper (2001) argue that accounting technologies and systems enable control and coercion within power relations, and enhance exploitation and inequality. Accounting research specifically challenges the controlling impact that accounting has on emerging economies. This research highlights the work of the IASB as an international accounting standard setter and the IFIs promoting globalism, through requiring the adoption of narrow accounting technologies (Annisette 2004, Arnold 2005, Gallhofer, Haslam and Kamla 2011). Neu (2000) and Neu, Rahaman and Everett (2014) draw on governmentality theory to examine the impact of accounting technologies, through logics of imperialism and colonialism, arguing that the ideologies of accounting institutes subalternity and unequal exchange. The World Bank's informing technologies enable them '... to govern and regulate action at a distance', within which accounting and financial expertise holds an oftenneglected role (Neu and Heincke 2004).

Gallhofer, Haslam and Kamla (2011) illustrate how the adoption of International Accounting Standards (promulgated by the IASB) in developing countries is a form of imperialism informed by Anglo-American, neo-liberal thinking. Sian $(2010,233)$ argues that ' $[t]$ he IASB and the global spread of International Financial Reporting Standards [IFRS] represent a new form of imperialism'. This demonstrates that the imposition of IFRS on emerging economies, in some instances has suppressed local culture and social interests (Poullaos 2004). For Hopper, Lassou and Soobaroyene (2017) the IASB promote a neo-liberal ideology through development logics that hold that developing countries should learn from developed countries, ignoring the local context and promulgating a 'Friedmenite Chicago' neo-liberal, 'one-size fits all' approach (Klien 2007). This is a crucial aspect of critical interventions, illustrating that accounting is a form of political and cultural domination (Miller and Rose 1995). This literature argues that the social implications of accounting for globalisation are often understated and Poullaos (2004) encourages academics to increase awareness of the 
social impacts and inequalities created by globalisation.

Creative accounting and the plurality of accounting meanings are important, and critical accounting literature emphasises the rhetorical nature of accounting technologies. There has been a developing accounting literature concerning accounting as a language of expropriation in a 'post-Fordist' economy, tracing the impacts of a shift towards a knowledge or immaterial-based economy (Hardt and Negri 2005): this literature illustrates attempts by accounting to expropriate the 'value' of immaterial labour (Spence and Carter 2011, Cooper 2015, Mäkelä 2013). This illustrates the cleverness of capital and the flexibility within accounting to extend its scope. As capital shifts from exploitation to expropriation, the tools and techniques of accounting are employed in different manners, shifting from techniques that measure the extraction of surplus value (exploitation, see Puxty 1993) to techniques that measure the financial valorisation of social life in the sense of the bien communs (Carter 2018). Thus, we argue that the IASB and new accounting developments (such as fair value accounting and the rise of derivative financial reporting) provides mechanisms for valorising advanced financial capital and indebtedness.

We argue that while critical accounting literature illustrates the role of accounting in exploitation and expropriation, this requires extension to argue that accounting is the language of appropriation (of time and social life) for the purposes of indebtedness within financial capital. We argue that the hidden power of accounting is a central agent in the genuflection to financial capital as accounting for indebtedness is accounting for futures and the enclosure of social life (Lazzarato 2012, 2013, Marazzi 2011). Accounting, therefore, is the language of advanced financial capital and indebtedness. In illustrating the centrality of accounting to Lazzarato's concept of indebtedness, our analysis of accounting focuses on how accounting expertise (as hidden power behind a technocratic veil) comes to appear as neutral whilst reflecting the dominance of accounting, financial capital, and key transnational institutional actors and agencies. Whilst critical accounting literature go some way in revealing to power of accounting, we see few papers in accounting that have extended their analysis of the scope of accounting to a geo-politics of control through financial capital. For example, Bryan and Rafferty (2014) argue that the way that financial derivatives operate involves the selling of 'tradeable risks' by rendering them open to financial calculus. This logic values increasing components of social life, the economic world and public policy domains. In a similar way, Barthold, Dunne and Harvie (2017) examine Occupy Wall Street social movement as a mechanism for resisting indebtedness and financialisation. However, we see further scope in studying the role of accounting as the language of indebtedness. This is because the perceived technocratic nature of accounting belies an active pursuit of spreading the hegemony of financial capital. Equally, our focus is on how indebtedness is mobilised and articulated by the IASB and international financial institutions (IFIs) and the impact of this mobilisation.

Accounting is being used to extend geographical and temporal scope, as indebtedness is an advanced capital technology. The IASB is operating a duality: the basic logic of accounting regulation is to facilitate global capital movement, which incorporates traditional stage one finance, such as share ownership and investment funding. However, what is often excluded from the analysis is that the IASB is, at the same time, facilitating advanced financial capital, which is stage two finance as evidenced by the core components of the GFC that include financialisation and the derivatives boom. Thus, the IASB promotes techniques for valorising advanced financial capital and indebtedness. In this sense, the introduction of International Financial Reporting Standards for Small and Medium-Sized Entities (IFRS for SMEs) is an 
example par excellence: a) while opening up opportunities for financial capital to invest in SMEs (especially in emerging economies) through a common international accounting language (the IASB states that meeting the needs of SMEs would simultaneously satisfy the needs of emerging economies); b) by enabling advanced financial capital access to SMEs, this enables SMEs to gain further access to international capital (debt), and thus, opens up SMEs and emerging economies to indebtedness. This reinforces the role of the IASB as a geopolitical agent for advanced financial capital.

\section{The IASB, indebtedness and geopolitics}

The IASB plays an important role in spreading accounting for indebtedness. The IASB, which was formed in 2001 as a private, not-for-profit, transnational policy maker for the regulation of accounting and financial reporting, ${ }^{3}$ originally developed accounting standards for listed entities on stock markets, with the stated objective of facilitating global capital movement through enhanced harmonisation and comparability (Camfferman and Zeff 2007, 2015). The IASB $(2017,1)$ reinforces this in their mission statement:

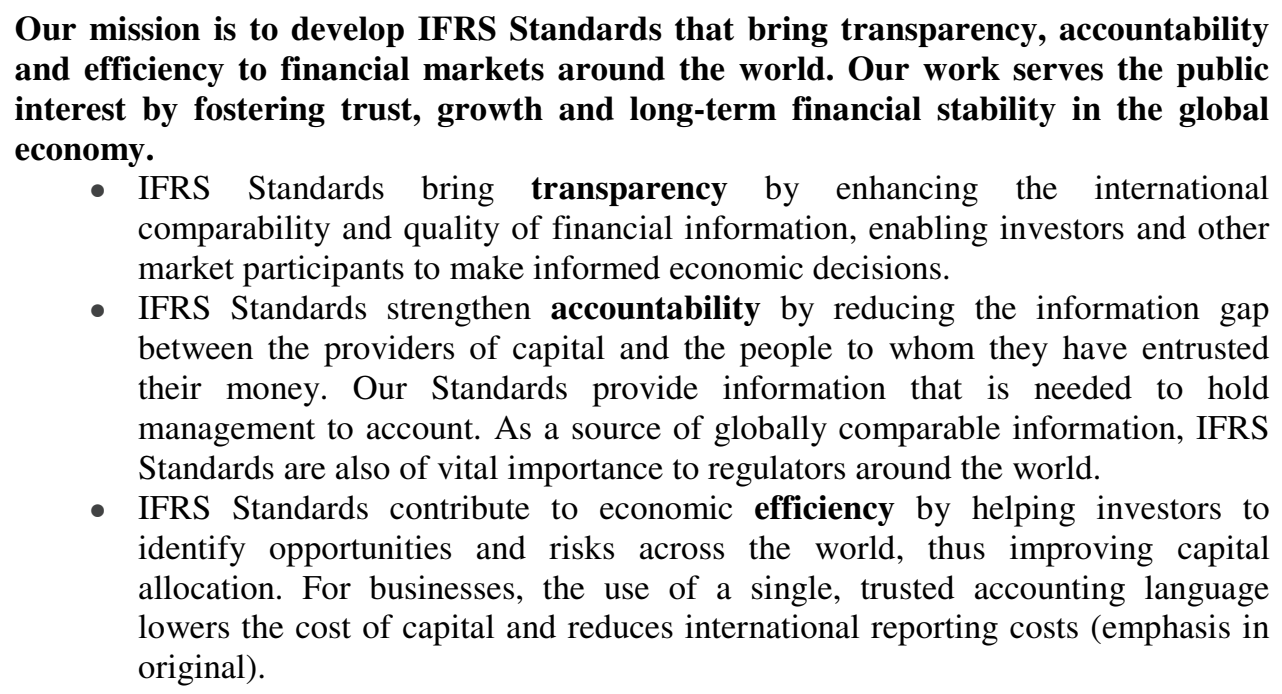

The IASB employs due process guidelines in constructing accounting standards, and has 14, trustee-appointed, members, alongside staff members (IFRS 2016). Currently, 119 countries, excluding the USA, have adopted IFRS-based financial reporting (IFRS 2016). The IASB is a self-regulatory body for accounting standard setting and their due process is presented as 'open', 'participatory' and 'transparent' (IFRS Foundation 2013).

\section{The IASB as an agent of advanced financial capital}

Within the stated objectives of comparability and facilitating global capital movement, the IASB is a central agent in the genuflection to financial capital (and advanced financial capital). The extent of adoption of international accounting standards illustrates the geo-

\footnotetext{
${ }^{3}$ Transnational accounting regulation has a relatively short history. Formal accounting regulation began post the 1929 stock market crash. Initial efforts focused on jurisdictionally based accounting regulation. The International Accounting Standards Committee was formed in 1973 as the first attempt at transnational regulation but was largely unsuccessful in harmonising accounting. However, there are other transnational accounting bodies concerning auditing and public sector accounting. The IASC was reconstituted as the IASB in 2001 and this led to significant harmonization (for a full history of international accounting standard setting see Camfferman and Zeff 2007, 2015, Nobes and Parker 2012).
} 
political influence of accounting regulation, as the IASB aims for global consistency for comparisons of companies and improvements in market efficiency:

Today, the world's financial markets are borderless. Companies (including small companies) seek capital at the best price wherever it is available. Investors and lenders seek investment opportunities wherever they can get the best returns commensurate with the risks involved. To assess the risks and returns of their various investment opportunities, investors and lenders need financial information that is relevant, reliable and comparable across borders. The use of one set of high quality standards by companies throughout the world improves the comparability and transparency of financial information and reduces financial statement preparation costs. When the standards are applied rigorously and consistently, capital market participants receive higher quality information and can make better decisions (Pacter 2015, 24).

The politics of accounting regulation and the implications of the shift to financial capital were exposed during the GFC. The GFC (with its three constituent movements from a derivative financial housing market crisis to a banking crisis to a sovereign debt crisis) illustrated the significant political influence of accounting regulation and the IASB (Botzem 2012). This authority and expertise is constructed through norm-setting, with shared values held by a small group of experts (Botzem and Hoffman 2010). The IASB have aligned accounting rules with capital market needs, creating transnational, 'technocratic', regulation. However, the GFC called this 'self-regulatory' model into question:

The financial crisis of 2007-2009 is frequently referred to as the most drastic and consequential episode in more than two generations ... Vibrant discussions of the reasons soon emerged and brought to prominence an aspect of financial market regulation that had previously been discussed only among experts: Accounting rules now become the object of heated debate ... Moreover, more than just accounting rules were criticised. The G20 called for immediate actions. In particular, it asked the standardisation body to review its membership, to enhance transparency, and to ensure appropriate relationships with public authorities. Political reactions to the financial crisis moved accounting standards and transnational standardisation bodies into a spotlight that they had successfully avoided for decades ... (Botzem 2012, 1-2).

In illustrating the geo-political influence of the IASB, the G20 called directly on the IASB to resolve the issues that emerged from the GFC:

The Declaration on Strengthening the Financial System issued by the leaders of the Group of 20 (G20) following their meeting in London on 2 April 2009 calls on the accounting standard setters to improve standards for determining the fair values of financial instruments in illiquid markets and to take other actions regarding complexity of financial reporting, provisioning, and off balance sheet financing, among other matters (Deloitte 2009, 1).

As stated above in the section on accounting and financialisation, the specific accounting techniques mentioned in this quote are particularly relevant to financial capital. In spite of the politicisation of accounting subsequent to the GFC, we argue that the IASB and IFIs acted in a manner to obfuscate as much as possible the deeply political impact of the IASB's agenda behind a veil of technocratic expertise. This illustrates the scope of the power and influence of the IASB and is illustrative of the 'hidden' geopolitical power of the IASB, as a transnational policy maker. Political science literature suggests that the veil of technocracy obscures the political nature of technocratic governance (Jennings 2011, Lövbrand and Stripple 2011), which is particularly so in self-regulatory environments (such as the IASB) (Larsson 2013, Chiapello and Medjad 2009). Many of the regulatory technologies developed by the IASB were in part blamed for the GFC. The IFRS Foundation $(2015,1)$ stated: 
By supposedly relying excessively on market-value-based fair-value accounting, the IASB is seen as having too little regard for prudence in accounting. Some believe that this promotes short-termism and excessive dividend policies in the capital markets.

What transpired is crucial: the IASB in effect 'doubled-down' on financial capital. This followed national capitalism and the IFIs who effectively reinforced financial capital, as there were cosmetic changes to techniques, but the essential technologies of indebtedness were reinforced. One indicator of this was the power of the US lobby on Capitol Hill to resist any substantive reform with respect to derivative financial markets. Langley $(2014,179)$ illustrates this:

There has been no coherent or explicit attempt to crisis-proof finance ... no concerted attempt to redesign global finance in order to prevent the next crisis. Rather, the rationale which gradually surfaced in the course of crisis management was to govern through, as opposed to against, uncertainty; to accept that the destructive forces which crystallise during crises are inherent to global financial circulations, and that trying to thwart future crises threatens to destroy the ostensibly productive contribution of those labile circulations ...

Thus, the IASB is firmly entrenched within financial capital hegemony. Consequently, the next section highlights how accounting is the language of indebtedness and the IASB operates as a geo-political agent for advanced financial capital enabling indebtedness.

\section{Technologies of accounting for indebtedness}

What is unquestioned in this analysis is that the State and IFIs play a central role in supporting the debt economies of advanced capitalist economies. The lessons of the GFC, the Eurozone debt crises and continued financial instabilities include the lack of financial regulation of derivatives, the continued liberalisation of financial/debt markets and the reinstitution of the status quo post-crisis through debt-funded bailouts. This is also evident in the technocratic architecture of IFIs (Christophers 2016, 141). Christophers (2016, 146) argues that IFRS is a central pillar in 'global financial governance', as Mügge and Stellinga $(2015,2)$ illustrate the importance of accounting, as 'banking regulation is no more stable than the asset valuations that feed it ... Accounting standards influence the asset values they only pretend to measure'.

However, the impact of the neo-liberal agenda is to construct the emerging economic world as an opportunity for profiteering for financial capital. As the hegemony of advanced financial capital is spread through economic imperialism, market liberalisation and structural adjustment, emerging economies are treated as indirect extensions of indebtedness (in the case of cheap labour, commodities and micro-credit) but also as a space for the extension of indebtedness, such as through public-private partnerships (Shaoul 1997). We argue that the impact of this is that emerging economies are being recreated as debt economies. Debt, in this instance, is the basis of social life. We argue that the IFIs are crucial to this as they play a central role in supporting debt economies and advanced financial capital.

Botzem (2012) outlines the interconnectedness of the IASB and IFIs, identifying that emerging economies feel coercive isomorphic pressure to adopt IFRS, pressure that comes from the IMF, the World Bank and the WTO in terms of access to development aid, finance and trade. The World Bank demands the adoption of a range of accounting technologies, including IFRS and more recently IFRS for SMEs (Neu and Ocampo 2007). As the IASB 
expands the reach beyond listed entities and capital markets to SMEs and emerging economies, these new movements in standards become incorporated into IFI requirements. Therefore, the World Bank is a key organisation in the standard setting framework, advanced financial capital and neoliberalism, and the World Bank is core to the IASB's network and power (Botzem 2012).

\section{Extending the scope of accounting for indebtedness}

The extension of accounting technologies to financialisation, derivatives and fair value accounting suggests a strong link between accounting regulation and the logic of advanced financial capital. Clarke $(2010,375)$ argues that many narratives centre on the "magic of the market', and thus, markets are "efficient and effective", as they are 'dynamic and responsive, innovative and open' (Clarke 2010, 375). IFIs and the IASB promise that tomorrow will be better and that access to financial capital markets are expansive. The IASB has stated aim of facilitating global capital mobility (Nobes and Parker, 2012), and this includes a 'promise' that wealth will continue to be created, there is always 'more wealth, more goods, more results, more possibilities' (Clarke 2010, 377). Moreover, there is always the promise that freeing markets will reduce global poverty as there is continuously new creation of wealth (Clarke 2010). This is part of the duality of IFIs and the IASB: by spreading a message of development and 'hope', this is hidden in mechanisms of advanced financial capital which transfers significant revenues or profit from emerging economies to advanced capital holders, and this lays the foundation for increasing indebtedness. Access is the key here and the IASB provides a common language for IFIs and financial rentiers. For example, two World Bank reports illustrate the centrality of accounting as a language of development through access to credit:
A simplified set of financial reporting standards would make it easier for SMEs to improve the quality of their financial information and, ultimately, to use that information to access credit. The International Accounting Standards Board (IASB) recently issued a simplified set of standards for financial reporting (referred to as "IFRS for SMEs" or "IFRS for Private Entities") that requires a lesser level of disclosure and eliminates the most complex options provided in IFRS, especially those requiring the use of fair values. The authorities in most LAC countries should consider adopting these standards for use by local SMEs - although there is legitimate concern in some countries that these standards might still be challenging to apply for entities at the smaller end of the corporate spectrum (Fortin, Barros and Cutler 2010, 113).
As an institution committed to the fight against poverty, the World Bank undertakes a number of activities to support the development and implementation of international accounting and auditing standards, as it recognises the contribution that high-quality financial reporting can make to development. These activities include financial support to the relevant international standard-setting organisations; diagnostic work to benchmark countries' financial reporting standards and practices against international standards; policy advice and financial assistance to support the enhancement of these standards and practices; and participation in international discussions and initiatives aimed at strengthening the regulatory environment, both nationally and globally, in which international standards are applied (Hegarty, Gielen and Barros 2004, $1-2)$.

These statements illustrate the role of accounting as a language of development, growth and a language central to facilitating indebtedness, by opening up opportunities for control:

The power of destruction/creation was and is not a property of money as such. Money must be transformed into capital, that is, into a power of destruction/creation. With neoliberalism, the stock market, finance and debt are the mechanisms that effectuate this transformation (Lazzarato 2012, 83). 
Accounting has always been an element of structural adjustment, particularly around the promulgation of best practice accounting technologies, with a focus on 'measurement' and comparability. However, with the accounting harmonisation movements of the IASB, the opportunities to institute financial capital hegemony has reconstituted the role of IFIs, as well, who spread IFRS adoption as part of structural adjustment. We suggest the IASB is important here in the internationalisation process of indebtedness.

\section{Accounting as the technology for the valorisation of futures and social life}

Debt is an appropriation machine, as it is a measurement device. The fundamental shift, as measured by the increasing valorisation of financial capital in accounting (as evidenced by derivative based accounting and the shifts to fair value accounting measurement), is that accounting language valorises the creditor-debtor relationship.

\footnotetext{
In the context of financially dominated capitalism, which has seen the expansion of financial markets and financial investment into non-financial sectors, [Fair Value Accounting] is the manifestation of this trend in the field of financial accounting. It is, in other words, the financialisation of accounting (Müller 2014, 555).
}

This is reinforced through the substance-over-form debate in accounting, where measurement and its impact on the financial position of the entity is the central issue: the complexities of lease accounting with respect to IAS 17 create peculiarities by which two ostensibly similar lease transactions can have markedly different impacts on disclosure, balance sheet positions (including liabilities and assets) and relative positions of liquidity. The financing lease, in this sense, creates a liability and an asset while the operating lease constitutes a form of offbalance sheet financing.

Hence, the increasing financialisation of accounting provides the mechanisms to valorise social life through valorising the indebtedness. As Adkins (2017) argues, without the ability to represent the value of indebtedness, the creditor-debtor relationship is rendered ineffective; the very essence of a net present value calculation is to be able to identify a value owed today against futures. This illustrates the combination of accounting and indebtedness, by simultaneously rewriting time (accounting for the future), providing a measurement ability for future values and valorising the finanicalised indebtedness. With respect to measurement, the derivative components of the GFC operated on the ability of financial rentiers to identify future returns against immediate capital outlay. In this way, the balance sheet measures some debt relationships and captures certain elements of the future; fair value recognises potential values tomorrow, liabilities are direct debts, equity is an indirect measure of shareholder debt. As Mellor $(2010,58)$ argues, '[f]inancialisation has increased the dominance of money and money value'.

Recent developments in accounting techniques provide mechanisms for accounting for debt, accounting for financialisation, accounting for 'futures' and accounting for the appropriation of social life. We argue that accounting is a driver of the valorisation of indebtedness, and thus, the violence of financial capital. Venn $(2009,226-227)$ illustrates the role of accounting (as a calculative technology):

My first point is that the universalisation of property and commodity as the principle determining value necessarily privileges the calculable over the incalculable, indeed reduces the incalculable to the status of the calculable; it must eliminate the ineffable and 
the spiritual, that is, everything relating to finitude, to the aesthetic and the ethical dimensions of being, thus, all the aspects of experience that humanise humans as specific beings and make life worth living. So, on the one side we have the 'destruction of the incalculable by calculation' ... based on the primacy of 'value for money' and of accounting practice as the framework determining the 'cold' and 'callous' calculus of an 'audit culture', consistent with the universalisation of the commodity form, and on the other side we have the values of responsibility for the other, the recognition of singularity, truth, justice, ethics as ultimate criteria for judging worth and the quality of life

In our opinion, there is a clear link between the GFC and the introduction of an accounting measurement system, entitled fair value accounting (cf. Laux and Leuz 2009). Fair value accounting is a measurement system applied to classes of assets such as derivative financial instruments which allows holders of those derivatives to recognise financial assets at market value, with reference to market prices on the same assets (which constitutes Level 1), similar assets and capital asset pricing models (which constitutes level 2) and if there is no appropriate available market value, then the value is determined through present value and other internally generated estimates (which constitutes level 3). These three levels lead to increased financialisation and advanced financial capital has implemented new debt measures and increased derivatives and this is at the heart of indebtedness because fair value accounting allows for the recognition of unrealised gains in assets. There is increasing literature linking debt and fair value accounting (although primarily from the firm perspective) (see, Lewis 2009, de Jager 2014).

There have been many problems caused by the use of fair value accounting, which is not limited to the financial crisis, but can be seen in many other accounting scandals (Benston 2006, Cooper 2015). Enron developed the early conceptions of fair value accounting and were key players in convincing the Securities and Exchange Commission to allow fair value accounting (as promulgated in FAS 157). Enron then employed fair value accounting in accounting for the future values to be earned from the Blockbuster video on demand deal (recognising at least $\$ 111$ million of revenue in one year when the project had made not a single dollar), and profited from the California energy crisis of 2000-2001 through recognising the difference between spot prices for electricity and the energy futures that they held the rights to as revenue. Despite this history, the IASB continues to support fair value accounting and responded to the GFC simply by tightening disclosure requirements. Note that the geo-political core of the G20, the IFIs and the IASB did not advocate for removing fair value accounting, but rather bringing it under control, which reinforces the hegemonic position of advanced financial capital. Consequently, this constitutes acceptance that this is the 'right way' to be doing accounting.

Financialisation, securitisation and fair value lead to a focus on accounting for futures, which as a central pillar of indebtedness reconstitutes time (Adkins 2017). Accounting as a technology constitutes, subsumes and constructs particular subjects within the abstract social processes of accounting (Hines 1988). In this, time is a complex issue. Quattrone $(2005,196$, 203) (in considering the industrial revolution) argues that:

... the achievement of a notion of time which is shared and objective requires the deployment of a series of techniques, technologies and beliefs ... among which accounting may play an important ... role. If today no one would contest that "time is money"... it is likely because the asset turnover ratio (and the double-entry bookkeeping behind it) has made the flowing of time visible, measurable and worthy. 
Ezzamel and Robson $(1995,149)$ suggest that accounting practices 'regulate and monitor economic transactions across time and space'. In this, accounting inscribes time into its processes, but due to the technologies of accounting, this is subject to manipulation, construction or contestation (Hines 1988). However, this is a conception of time rooted in notions of industrial capital. Time is an effective control mechanism, with respect to material labour. This preoccupation with measurement and time is one of the prime measures and a source of fundamental control for management accounting according to Nandhakumar and Jones (2001, 194):

Time in accounting is predominantly conceptualised in terms of measurable clock time... which enables precise timing of activities and thereby their coordination across a particular place... clock-time is an important feature of capitalism, necessary for the control of the labour process. Through standards, budgets and plans, accounting therefore seeks to mobilise cost and effort in temporal terms and to manage time as a scarce resource. In this way, accounting is seen as providing a neutral, objective and calculable domain that would allow organisations to be governed.

However, this logic has been problematised for immaterial labour in knowledge capital, as time measures in immaterial capital:

... reify the material element of the work (sales, customers, care, linking time to output, papers etc.) and thus, this constitutes a congenital failure to address the immaterial element of the labour process. However, these become a proxy for control and a valorisation process of 'what, how, how much, why and who of social production' (Carter 2018, 245).

This challenge concerning time is relevant to accounting, as well, because advanced financial capital institutes a new form of control of time. This is not time in the industrial or knowledge capital sense. Progressively the measure of indebtedness is not monetary per se (although of course debt is expressed economically) but it incorporates the purchase of time in the sense of the purchase of futures. As Lazzarato $(2013,70)$ suggests, 'credit produces a specific form of subjectivation', because '[d]ebt bridges the present and future, it anticipates and pre-empts the future'. Fair value accounting is this technique - a much parodied Enron video introduced fair value accounting as 'hypothetical future value accounting' (see, Enron: The Smartest Guys in the Room). Thus, this is a significant development in accounting measurement. Traditional time measures were productive in origin through the Fordist focus of industrial capital; time is expropriated through immaterial valorisation, but an expression of debt, in accounting terms, is not simply a measure of indebtedness, but measures the purchase of future time (Goux 1990). Thus, accounting for advanced financial capital and indebtedness reconstitutes time in accounting by allowing for a measurement of futures to come, which is an appropriation of social life.

Furthermore, if we accept Adkins' (2017) conception that financialisation in the form of indebtedness is 'real', then this indicates that fair value accounting, as an accounting technique for "bridging the gap between present and future", is also a technique for appropriating social life. Terranova (2015) illustrates how the financial market as a norm enslaves society, and Allon (2010) takes this further to illustrate that daily life is increasingly viewed as a financialisation opportunity. Equally, as fair value is the measurement device for derivative-based financialisation, this provides the mechanism for capturing the value of social life, as 'securitisation therefore involves a rewriting of the social life' (Adkins 2017, 10)

In many ways accountants do not question their own frameworks, instead accountants will often make decisions without considering the theoretical impact or questioning the 
framework that they are based on (Hines 1988, Morgan 1988, Wolcher 2007). Morgan (1988) explains this, identifying the cultures of accounting, and the manner in which accounting often does not consider the consequences of its decisions and actions. Lazzarato (2012) argues a similar point, as indebtedness moves to account for futures there is no consideration of the people and the countries that are affected. Accounting is important for this as the methodology of accounting has depoliticised this form of appropriation, because the language of accounting only acts in favour of global capital movement and shareholder wealth maximisation.

\section{Conclusion}

This paper reflects on the implications of hegemonic shifts between capitalism and capitals (industrial, knowledge and financial), examining the shift towards financial capital. In particular, the impact of the GFC and the increased signification of debt and 'indebtedness' with respect to the individual and with respect to sovereign nations, are constituent components of this intervention (Lazzarato 2012, 2013, Graeber 2011, Mellor 2010). Researchers have illustrated the traditional role of accounting in relation to industrial capital as a powerful tool for owners of capital to protect their privileges, power and wealth, through the maintenance and enhancement of that power and wealth (Harney 2005, Puxty 1993). Within this paper, by focusing on Lazzarato's theory of indebtedness to analyse accounting, we have shown that accounting is the language of advanced financial capital and indebtedness, and has a hidden power within society, as it is perceived as technical and neutral. We have highlighted three components of accounting for indebtedness in relation to time, measurement and the valorisation of social life. This provided the foundations for three arguments: First, we illustrated the role for the IASB in association with IFIs to mobilise indebtedness as accounting has been constructed as the language for the hegemonic spread of advanced financial capital. This we argue is the structural mechanism for appropriation of social life through extending the scope of financial capital. Second, we illustrated how accounting technologies such as fair value reconstitute the concept of time within accounting. Time was money as a measurement device but within fair value and indebtedness, accounting for time is accounting for future life. The third component of this is that by accounting for future life, this exercise of control and constraint as contained within the creditor-debtor relationship constitutes an enclosure of social life such that accounting for indebtedness is accounting for social life. The problem here is that debt permeates so much of social life. Accounting is the language of advanced financial capital and is used then as a mechanism for appropriate futures and social life in a form of monetary representation. However, knowledge of this political economy of indebtedness does not necessarily provide you with a toolkit for escaping its clutches. The problem here is the pervasiveness of indebtedness and the impact of accounting for advanced financial capital. 


\section{References}

Adkins, L. 2017. "Speculative futures in the time of debt”. The Sociological Review, 1-15.

Allon, F. 2010. "Speculating on everyday life: The cultural economy of the quotidian". Journal of Communication Inquiry, 34(4), 366-381.

Annisette, M. 2004. "The true nature of the World Bank". Critical Perspectives on Accounting, 15(3), 303-323.

Arnold, P. J. 2005. "Disciplining domestic regulation: the World Trade Organisation and the market for professional services". Accounting, Organizations and Society, 30(4), 299330.

Arrington, E, C., and Puxty, A. G. 1991. "Accounting, interests, and rationality: a communicative relation". Critical Perspectives on Accounting, 2(1): 31-58.

Barthold, C., Dunne, S. and Harvie, D. 2017. "Resisting financialisation with Deleuze and Guattari: the case of Occupy Wall Street". Critical Perspectives on Accounting, in press.

Benston, G. J. 2006. "Fair-value accounting: A cautionary tale from Enron". Journal of Accounting and Public Policy, 25(4), 465-484.

Botzem, S. 2012. The politics of accounting regulation: Organising transnational standard setting in financial reporting. Cheltenham: Edward Elgar Publishing.

Botzem, S., and Hofmann, J. 2010. "Transnational governance spirals: The transformation of rule-making authority in internet regulation and corporate financial reporting". Critical Policy Studies, 4(1), 18-37.

Brown, J., and Dillard, J. 2013. "Agonising over engagement: SEA and the "death of environmentalism" debates". Critical Perspectives on Accounting, 24(1), 1-18.

Bryan, D. and Rafferty, M. 2014. "Financial derivatives as social policy beyond crisis". Sociology, 48(5), 887-903.

Camfferman, K., and Zeff, S. A. 2007. Financial Reporting and Global Capital Markets: A History of the International Accounting Standards Committee, 1973-2000. Oxford: Oxford University Press.

Camfferman, K., and Zeff, S. A. 2015. Aiming for global accounting standards: the International Accounting Standards Board, 2001-2011. USA: Oxford University Press.

Carter D.B. 2018. Accounting for the immaterial, in E. Harris (ed) The Routledge Companion to Performance Management and Control. London: Routledge.

Catlett, G. R. 1960. "Factors that influence accounting principles". Journal of Accountancy, 44-50.

Chiapello, E. and Medjad, K. 2009. "An unprecedented privatisation of mandatory standardsetting: The case of European accounting policy". Critical Perspectives on Accounting, 20(4): 448-468

Christophers, B. 2016. "Geographies of finance III: Regulation and 'after-crisis' financial futures". Progress in Human Geography, 40(1), 138-148.

Chua, W. F. 1986. Radical developments in accounting thought. Accounting review, 601-632.

Clarke, J. 2010. "After neo-liberalism? Markets, states and the reinvention of public welfare". Cultural Studies, 24(3), 375-394. 
Coleman, W.D. 2016. Financial services, globalization and domestic policy change. New York: Springer.

Cooper, C. 2015. "Accounting for the fictitious: A Marxist contribution to understanding accounting's roles in the financial crisis". Critical Perspectives on Accounting, 30, 63-82.

Cooper, D. J., and Sherer, M. J. 1984. "The value of corporate accounting reports: arguments for a political economy of accounting". Accounting, Organizations and Society, 9(3): 207-232.

Covaleski, M. A., Dirsmith, M. W., and Samuel, S. 2003. "Changes in the institutional environment and the institutions of governance: extending the contributions of transaction cost economics within the management control literature". Accounting, Organizations and Society, 28(5), 417-441.

de Jager, P. 2014. Fair value accounting, fragile bank balance sheets and crisis: A model. Accounting, Organizations and Society, 39(2), 97-116

Deleuze, G. 1995. Negotiations, 1972-1990. New York: Columbia University Press.

Deleuze, G. and Guattari, F. 1975. Anti-Oedipe. Paris: Les editions de Minuit.

Deloitte. 2009. G20 declaration and IASB response. London: IAS Plus. https://www.iasplus.com/en/news/2009/April/news4621.

Di Federici, S. 2014. "From commoning to debt: Financialization, microcredit, and the changing architecture of capital accumulation". South Atlantic Quarterly, 113(2), 231244.

Efferin, S., and Hopper, T. 2007. "Management control, culture and ethnicity in a Chinese Indonesian company". Accounting, Organizations and Society, 32(3), 223-262.

Erkkilä, T., and Piironen, O. 2014. "(De) politicising good governance: the World Bank Institute, the OECD and the politics of governance indicators". Innovation: The European Journal of Social Science Research, 27(4), 344-360.

Ezzamel, M., and Robson, K. 1995. “Accounting in time: organizational time-reckoning and accounting practice". Critical Perspectives on Accounting, 6(2), 149-170.

Fortin, A. Barros. A. and. K. Cutler. 2010. Accounting for Growth in Latin America and the Caribbean, Washington DC: World Bank.

Gaffikin, M. 2008. Accounting theory: Research, regulation and accounting practice. Frenchs Forest, N.S.W.: Pearson Education.

Gallhofer, S., and Haslam, J. 2003. Accounting and emancipation: some critical interventions. London: Routledge.

Gallhofer, S., and Haslam, J. 2007. "Exploring social, political and economic dimensions of accounting in the global context: the International Accounting Standards Board and accounting disaggregation". Socio-Economic Review, 5(4), 633-664.

Gallhofer, S., Haslam, J., and Kamla, R. 2011. The accountancy profession and the ambiguities of globalisation in a post-colonial, Middle Eastern and Islamic context: Perceptions of accountants in Syria. Critical Perspectives on Accounting, 22(4), 376-395.

García-Lamarca, M. and Kaika, M. 2016. “'Mortgaged lives': the biopolitics of debt and housing financialisation". Transactions of the Institute of British Geographers, 41(3), 313-327. 
Gill, M. 2009. Accountants' Truth: Knowledge and Ethics in the Financial World. Oxford University Press: New York.

Goux, J.J. 1990. Symbolic Economies: After Marx and Freud. (Trans. J. Curtiss Gage). New York: Cornell University Press.

Graeber, D. 2011. Debt: The First 5,000 Years. New York: Melville House Publishing.

Gray, R. 2001. Thirty years of social accounting, reporting and auditing: what (if anything) have we learnt?. Business ethics: A European review, 10(1), 9-15.

Gregory, C.A. 2012. On money debt and morality: some reflections on the contribution of economic anthropology. Social Anthropology, 20(4), 380-396.

Guérin, I. 2014. Juggling with debt, social ties, and values: the everyday use of microcredit in rural South India. Current Anthropology, 55(9), S40-S50.

Guyer, J. I. 2012. "Life in financial calendrics". Available at: http://www.culanth.org/ fieldsights/338-life-in-financial-calendrics (accessed: 3 March 2016).

Hardt, M. and Negri, A. 2005. Multitude: War and Democracy in the Age of Empire. New York: Penguin Press.

Hardt, M. and Negri, A. 2009. Commonwealth. Cambridge: Belknap.

Harney, S. 2005. Why is management a cliché?: Critical Perspectives on Accounting, 16(5), 579-591.

Harney, S. 2006. "Management and self-activity: Accounting for the crisis in profit-taking". Critical Perspectives on Accounting, 17(7), 935-946.

Harvey, D. 2010. A companion to Marx's capital. London: Verso.

Hegarty, J., Gielen, F. and Barros, A. C. H. 2004. Implementation of International Accounting and Auditing Standards: Lessons Learned from the World Bank's Accounting and Auditing ROSC Program. Washington D.C: World Bank.

Hines, R. D. 1988. "Financial accounting: In communicating reality, we construct reality". Accounting, Organizations and Society, 13(3), 251-261.

Hines, R.D. 1991. "The FASB's conceptual framework, financial accounting and the maintenance of the social world". Accounting, Organizations and Society, 16(4), 313331.

Hoffman, W. M. 1984. "Case Study: The Ford Pinto”. Business Ethics, 222-229.

Hopper, T., Lassou, P., and Soobaroyen, T. 2017. "Globalisation, accounting and developing countries." Critical Perspectives on Accounting, 43, 125-148

IASB. 2017. "About Us: Mission Statement" Available at: http://www.ifrs.org/Aboutus/Pages/IFRS-Foundation-and-IASB.aspx

IASB. 2013. IFRS 13 - Fair Value Measurement. Available at https://www.iasplus.com/en/standards/ifrs/ifrs13.

IFRS Foundation. 2013. Due Process Handbook: Feedback Statement. London: IFRS Foundation. Available

at: http://www.ifrs.org/DPOC/Documents/2013/Due_Process_Handbook_Resupply_28_Feb 2013 WEBSITE.pdf 
IFRS Foundation. 2015. Working in the Public Interest: The IFRS Foundation and the IASB. London: IFRS Foundation. Available at: http://www.ifrs.org/Aboutus/Documents/Working-in-the-Public-Interest.pdf.

IFRS. 2016. The Global Financial Reporting Language. London: IFRS Foundation.

Jennings, B. 2011. "Poets of the common good: experts, citizens, public policy". Critical Policy Studies, 5(3), 334-339.

Klein, N. 2007. The shock doctrine: The rise of disaster capitalism. Macmillan.

Langley, P. 2014. Liquidity Lost: The Governance of the Global Financial Crisis. Oxford: Oxford University Press.

Larsson, O. L. 2013. "Sovereign power beyond the state: a critical reappraisal of governance by networks". Critical Policy Studies, 7(2), 99-114.

Laux, C., and Leuz, C. 2009. "The crisis of fair-value accounting: Making sense of the recent debate". Accounting, organizations and society, 34(6), 826-834.

Lazzarato, M. 2012. The making of the indebted man: An essay on the neoliberal condition. Amsterdam: Semiotext(e).

Lazzarato, M. 2013. Governing by debt. Pasadena: Semiotext(e).

Lewis, M.K. 2009, June. The origins of the sub-prime crisis: Inappropriate policies, regulations, or both? Accounting Forum, 33(2), 114-126.

Lövbrand, E., and Stripple, J. 2011. "Making climate change governable: accounting for carbon as sinks, credits and personal budgets". Critical Policy Studies, 5(2), 187-200.

Major, M., and Hopper, T. 2005. "Managers divided: Implementing ABC in a Portuguese telecommunications company". Management Accounting Research, 16(2), 205-229.

Mäkelä, H. 2013. "On the ideological role of employee reporting”. Critical Perspectives on Accounting, 24(4), 360-378.

Marazzi, C. 2011. The violence of financial capitalism. Pasadena: Semiotext(e).

Mellor, M., 2010. The future of money: From financial crisis to public resource. London: Pluto Press.

Miller, P. and Rose, N. 1995. "Production, identity, and democracy". Theory and society, 24(3), 427-467.

Mitchell, T. 2002. Rule of experts: Egypt, techno-politics, modernity. Univ of California Press.

Mol, A. and Law, J. 2004. "Embodied action, enacted bodies: the example of hypoglycaemia”, Body \& Society, 10(2-3), 43-62.

Morgan, G. 1988. "Accounting as Reality Construction: Towards a New Epistemology for Accounting Practice". Accounting, Organizations and Society, 13(5), 477-485.

Mouck, T. 1992. "The Rhetoric of Science and the Rhetoric of Revolt in Positive Accounting Theory". Accounting, Auditing and Accountability, 5(4): 35-56.

Mügge, D., and Stellinga, B. 2015. "The unstable core of global finance: Contingent valuation and governance of international accounting standards". Regulation \& Governance, 9(1), 47-62. 
Müller, J. 2014. An accounting revolution? The financialisation of standard setting. Critical Perspectives on Accounting, 25(7), 539-557.

Nandhakumar, J., and Jones, M. 2001. Accounting for time: managing time in project-based teamworking. Accounting, Organizations and Society, 26(3), 193-214.

Neu, D. 2000. "Presents" for the "Indians": land, colonialism and accounting in Canada. Accounting, Organizations and Society, 25(2), 163-184.

Neu, D., and Heincke, M. 2004. "The subaltern speaks: financial relations and the limits of governmentality". Critical Perspectives on Accounting, 15(1): 179-206.

Neu, D., and Ocampo, E. 2007. "Doing missionary work: The World Bank and the diffusion of financial practices". Critical Perspectives on Accounting, 18(3): 363-389.

Neu, D., Rahaman, A. S., and Everett, J. 2014. Accounting and sweatshops: enabling coordination and control in low-price apparel production chains. Contemporary Accounting Research, 31(2), 322-346.

Nietzsche, F. 2006. On the Genealogy of Morality and Other Writings. C. Diethe (trans.) Cambridge: Cambridge University Press.

Nobes, C., and Parker, R. H. 2008. Comparative international accounting. Pearson Education.

Pacter, P. 2015. IFRS as global standards: a pocket guide. London: IFRS Foundation.

Peebles, G. 2010. The anthropology of credit and debt. Annual Review of Anthropology, 39, 225-240.

Poullaos, C. 2004. "Globalisation, accounting critique and the university". Critical Perspectives on Accounting, 15(4), 715-730.

Puxty, A. 1993. The Social and Organizational Content of Management Accounting. London: Academic Press Paperback.

Quattrone, P. 2005. "Is time spent, passed or counted? The missing link between time and accounting history”. The Accounting Historians Journal, 185-208.

Ram, R., and Newberry, S. 2013. "IFRS for SMEs: The IASB's due process". Australian Accounting Review, 23(1): 3-17.

Shaoul, J. 1997. The power of accounting: reflecting on water privatization?. Accounting, Auditing \& Accountability Journal, 10(3), 382-405.

Sherer, T. and Arrington, C.E. 1991. "Accounting in other Wor(l)ds: A Feminism without Reserve", Accounting, Organizations and Society, 18, 253-272.

Sian, S. 2010. Between the Lines: The Professionalization of Accountancy in Kenya. In Poullaos, C., and Sian, S. (Eds.). 2010. Accountancy and empire: The British legacy of professional organization. Routledge.

Sneath, D. 2012. The 'age of the market' and the regime of debt: the role of credit in the transformation of pastoral Mongolia. Social Anthropology, 20(4), 458-473.

Spence, C. and Carter, D.B. 2011. "Accounting for the general intellect: immaterial labour and the social factory". Critical Perspectives on Accounting, 22(3), 304-315.

Terranova, T. 2015. "Introduction to Eurocrisis, neoliberalism and the common". Theory, Culture \& Society, 32(7-8), 5-23. 
Thomas, C. W. 2002. "The rise and fall of Enron". Journal of Accountancy, 193(4), 41.

Uddin, S., and Hopper, T. 2001. "A Bangladesh soap opera: privatisation, accounting, and regimes of control in a less developed country". Accounting, organizations and society, 26(7), 643-672.

Vadrot, A.B.M. 2012. "Social movements, criticism of capitalism and the transformation of society: crisis and critique in the twenty-first century". Innovation: The European Journal of Social Science Research, 25(3), 247-250.

Vadrot, A.B.M. 2017. "Knowledge, international relations and the structure-agency debate: towards the concept of "epistemic selectivities". Innovation: The European Journal of Social Science Research, 30(1), 61-72.

Vadrot, A.B.M. 2017. "Knowledge, international relations and the structure-agency debate: towards the concept of "epistemic selectivities". Innovation: The European Journal of Social Science Research, 30(1), 61-72.

Venn, C. 2009. "Neoliberal political economy, biopolitics and colonialism: A transcolonial genealogy of inequality". Theory, Culture \& Society, 26(6), 206-233.

Wickramasinghe, D., and Hopper, T. 2005. "A cultural political economy of management accounting controls: a case study of a textile Mill in a traditional Sinhalese village". Critical Perspectives on Accounting, 16(4): 473-503.

Wolcher, L. E. 2007. "Senseless kindness: The politics of cost-benefit analysis". Law \& Inequality, 25, 147-202. 